\title{
Rearing technology for climbing fish (Anabas testudineus) on different salinity
}

\author{
Ani Widiyati ${ }^{1, *}$, B.N. Asyiah ${ }^{2}$, Tri Heru Prihadi ${ }^{1}$, and Dewi Puspaningsih ${ }^{1}$ \\ ${ }^{1}$ Research Institute for freshwater Aquaculture and Fisheries Extension, J1.Sempur No.1, Bogor, \\ Indonesia \\ ${ }^{2}$ Student of Department of Biology, Faculty of Mathematic and Science, University of Indonesia, \\ Jakarta, Indonesia
}

\begin{abstract}
Optimal salinity on rearing media is needed to get the best production performance of climbing fish culture. The aim of this experiment is to get an optimal salinity on rearing media of climbing fish. This experiment was conducted in wet lab of Research Institute for freshwater Aquaculture and Fisheries Extension. The treatments were different salinities on rearing media; 0 ppt, 3 ppt, 6 ppt and 9 ppt. Each treatment has 3 replicates. Experiment design use completely randomized design. The initial weight of fish was $1 \pm 0.11 \mathrm{~g}$ and initial length of fish was $2 \pm 0.3 \mathrm{~cm}$. Aquaria of $40 \times 22 \times 20 \mathrm{~cm}$ was used for rearing media. Each aquarium with $15 \mathrm{lt}$ of water was stocked 350 fish. Fish was fed frozen blood worm (protein contains of $62.5 \%$ ) at ad libitum. Duration time of rearing was 40 days. Sampling was conducted every 10 day for fish weight, lenght and water quality. The result showed that optimal salinity of survivale rate, specific growth rate and total length were on salinity of $1.8 \mathrm{ppt}, 2.5 \mathrm{ppt}$ and $3.3 \mathrm{ppt}$. The value of water quality parameter in aquaria such as temperature, $\mathrm{pH}$, Oxygen, nitrite, nitrate an amonia is still feasible for climbing fish rearing.
\end{abstract}

\section{Introduction}

Climbing fish (Anabas testudineus) is a kind of fresh water and brackish water specific local fish [1] and has high economic value in Sumatra and Kalimantan. Demand of climbing fish as food increase significantly, however population of climbing fish is decreasing in their habtitat $[10,7]$. Culture technology is needed to develop a climbing fish production, any efforts of culture was conducted but production is still low. This case predicted caused of unsuitable water quality. Water quality condition is related to capability to get sucsesfully aquaculture.

\footnotetext{
*Corresponding author: ani_widiyati@yahoo.co.id
} 
Water quality condition affects fish physiology proccess so it can be a limited factor. Salinity one of water quality parameter affects directly to fish metabolism. Too high, too low and big different fluctuated salinity would cause fish death. Salinity will affect directly by osmotic pressure dan osmoregulation proccess. Kaneko and Hiroi [11] said omoregulation process is needed to control water balancing and ion between in the fish body and environment so physiology process in fish body works normally.

Climbing fish was found on swamp area in South kalimantan. Swamp was area which watering affected by tidal of sea water, salinity fluctuated from $0-20 \mathrm{ppm}$ [16]. Fluctuated salinity was susceptible from survival rate of fry because it has big osmotic pressure. Osmoregulation process was needed to control water balance of ions between fish body and environment so that physioligy process in fish body works normally $[8,11]$. And hence, salinity was an urgent limiting factor to fish survival in aquaculture.

Many researchers conducted culture experiment of climbing fish, however no one researcher did an optimal salinity on rearing media to get maximum productivity from rearing technology of climbing fish fry.

\section{Materials and methods}

Experimental design used was Completely random Design with 4 treatments and 3 replicates. The treatments of rearing media salinity were $0 \mathrm{ppt} ; 3 \mathrm{ppt} ; 6 \mathrm{ppt} ; 9 \mathrm{ppt}$. Fish fry was got from naturally breeding, with initial length was $2-3 \mathrm{~cm}$, density of fry was 2 per litre. Fish was adapted before treatment as long as 60 days. Fish was reared 40 days. Sampling was conducted every 10 day to get weigh and length gain. Size of aquarium was $40 \times 22 \times 20 \mathrm{~cm}$ with water volume of 15 litre. Feed for feeding fish was blood worm with protein contains was $62.5 \%$. feed fed et ad libitum, 3 times a day, at $08.00 \mathrm{am}, 12.00 \mathrm{am}$ and $17.00 \mathrm{pm}$.

Parameters evaluated were Total growth weight, spesific growth rate, feed conversion, water quality and survival rate. Salinity on media was checked everyday while water temperature, disolve oxygen, $\mathrm{pH}$ and amonia were checked every 10 days. Data were analyzed using ANOVA for growth, survival rate and feed conversion while water quality was analyzed by deskriftive analysis. Polinomial orthogonal was used with tolerant significance of $95 \%$.

\section{Result and Discussion}

Specific growth rate (SGR), total weight gain, total lenght gain, feed efficiency, and survival rate of climbing fish fry from each treatment on 40 days rearing time could be seen on table 1. Treatment of $0 \mathrm{ppt}, 3 \mathrm{ppt}, 6 \mathrm{ppt}$ and $9 \mathrm{ppt}$ showed significant different on survival rate $(\mathrm{P}>0.05)$. Rearing on media 0 ppt with $67.78 \%$ was the best survival rate, while media on 9 ppt with $46.67 \%$ was the worse survival.

Reriang media of 0 ppt ( 0 ppt treatment), 3 ppt, 6 ppt and 9 ppt gave significant difference on specific growth rate $(\mathrm{P}<0.05)$. rearing media of $0 \mathrm{ppt}$ gave the best specific groth rate with $5.61 \%$, however 9ppt gave the worse with $4.53 \%$.

All treatments of media rearing ( 0 ppt, 3 ppt, 6 ppt and $9 \mathrm{ppt})$ gave significant difference on total weight gain and length gain $(\mathrm{P}<0.05)$. rearing media of 0 ppt gave the best total weight gain with $2.73 \mathrm{~g}$, however $9 \mathrm{ppt}$ gave the worse with 1.83 . 
Feed eficiency gave significant difference among tratments $(0,3,6$ and $9 \mathrm{ppt})$. The best feed efficiency was from treatment on rearing media of 3 ppt with $64.70 \%$ however the worse from 9 ppt with $49.26 \%$.

Table 1 showed the value of water quality parameters on all treatments during rearing.

Table 1. Value of specific growth rate (SGR), total weigh gain, total length gain, feed efficiency and survival rate for climbing fish fry during rearing period (40 days)

\begin{tabular}{|l|c|c|c|c|}
\hline \multirow{2}{*}{ Parameter tests } & \multicolumn{4}{|c|}{ Treatments (rearing media) } \\
\cline { 2 - 5 } & $0 \mathrm{ppt}$ & $3 \mathrm{ppt}$ & $6 \mathrm{ppt}$ & $9 \mathrm{ppt}$ \\
\hline SGR (\%) & $5.61 \pm 0.20^{\mathrm{a}}$ & $5.01 \pm 0,15^{\mathrm{ab}}$ & $4.61 \pm 0.62^{\mathrm{b}}$ & $4.53 \pm 0.48^{\mathrm{b}}$ \\
\hline Total weigh gain (g) & $2.73 \pm 0.10^{\mathrm{a}}$ & $2.38 \pm 0.24^{\mathrm{ab}}$ & $2.02 \pm 0.40^{\mathrm{ab}}$ & $1.83 \pm 0.30^{\mathrm{b}}$ \\
\hline Feed efficiency (\%) & $53.01 \pm 4.58^{\mathrm{ab}}$ & $64.70 \pm 9.00^{\mathrm{a}}$ & $56.52 \pm 4.50^{\mathrm{ab}}$ & $49.2 \pm 4.29^{\mathrm{b}}$ \\
\hline Survival rate (\%) & $67.78 \pm 6.94^{\mathrm{a}}$ & $60.00 \pm 5.77^{\mathrm{a}}$ & $55.56 \pm 1.92^{\mathrm{ab}}$ & $46.67 \pm 6.67^{\mathrm{b}}$ \\
\hline
\end{tabular}

Note : Value followed the same Superscript word showed no significant difference among treatments $(\mathrm{P}>0,05)$.

Table 2 showed water quality parameter value on rearing media for climbing fish fry from all treatments $(0,3,6$ and $9 \mathrm{ppt})$.

Table 2. Value of water quality parameters of rearing media from all treatments

\begin{tabular}{|l|c|c|c|c|}
\hline \multirow{2}{*}{ Parameters } & \multicolumn{4}{c|}{ Treatments } \\
\cline { 2 - 5 } & $0 \mathrm{ppt}$ & $3 \mathrm{ppt}$ & $6 \mathrm{ppt}$ & $9 \mathrm{ppt}$ \\
\hline Temperatur $\left({ }^{0} \mathrm{C}\right)$ & $25,5-26,4$ & $25,8-26,3$ & $25,6-26,6$ & $25,8-26,2$ \\
\hline $\mathrm{pH}$ & $6,0-6,7$ & $5,8-7,1$ & $6,0-7,20$ & $6,2-7,2$ \\
\hline Salinity $(\mathrm{ppt})$ & 0 & $3-3,5$ & $6-6,5$ & $9-9,5$ \\
\hline $\mathrm{DO}\left(\mathrm{mg} / \mathrm{l} \mathrm{O}_{2}\right)$ & $5,58-9,41$ & $5,47-8,69$ & $5,48-8,66$ & $5,41-8,93$ \\
\hline Amonia $\left(\mathrm{mg} / \mathrm{l} \mathrm{NH} \mathrm{N}_{3}\right)$ & $0,90-1,30$ & $0,60-1,30$ & $0,83-1,50$ & $1,0-1,7$ \\
\hline
\end{tabular}

Value of SGR decreased if salinity increased, this happened was occured because climbing fish fry tended more stress cause of salinity, so that fish would use more energi to balance lose salinity by non active diffusion. Energy got from feed was foccused to control capability fish adapted with environment so that the growth became slow and decreasing [22]. Garcia [9] added, salinity on rearing media can give bad effect on fish physiology mecanism, such as decreasing on growth. According to Ye [21] and De Boeck [5] decreasing on growth was predicted lack of input nutrient caused no availabity of suitable salinity.

Relathionship between salinity $(\mathrm{x})$ and specific growth rate (SGR) has coefficien value $\left(\mathrm{R}^{2}\right)$ was $79.3 \%$. it means any changing $79.3 \%$ of SGR was affected by salinity. Based on formula $Y=73.04+1,03 \mathrm{x}+-0.20 \mathrm{x}^{2}$, was found optimum salinity of $2.5 \mathrm{ppt}$ for specific growth rate.

Relathionship between salinity $(x)$ and total growth gain has coefficien value $\left(\mathrm{R}^{2}\right)$ was $79.3 \%$. it means any changing $79.3 \%$ of total growth gain was affected by salinity. Based on formula $\mathrm{Y}=3.19+0.4 \mathrm{x}+-0.14 \mathrm{x}^{2}$, was found optimum salinity of $2.8 \mathrm{ppt}$ for total growth gain. Relathionship between salinity $(\mathrm{x})$ and total length gain has coefficien value $\left(\mathrm{R}^{2}\right)$ was $80.9 \%$. it means any changing $80.9 \%$ of total length gain was affected by salinity. Based on formula $\mathrm{Y}=3.49+1.00 \mathrm{x}-0.15 \mathrm{x}^{2}$, was found optimum salinity of 3.33 ppt for total length gain. 
Salinity of 9 ppt was the worse feed efficiency with value of $49.26 \%$, this happenned was predicted more stress with increasing salinity. Energy got from feed in advance was used for osmoregulation procces, so that feed was in efficiency. According Andrianto (2005) high and low salinity on rearing media affect directly to feed efficiency and feed consumed. As well as Bardach et al. (1972) in Rahmadani [17] said feed efficiency was affected by stress and so feed consumed decreasing.

Salinity of 3 ppt was the highest feed efficiency with value of $64.70 \%$, but if compared to growth gain on salinity of 3 ppt was 2.38 gram and still under treatment salinity of $0 \mathrm{ppt}$ with 2.73 gram. This showed that feed was consumed by climbing fish fry on $3 \mathrm{ppt}$ treatment was in efficiency for growth because part of energy gor feed consumed was used for osmoregulation procces and for balancing too high salinity in environment condition. The more feed efficiency the more energy produced for osmoregulation procces and part of it was used for growth.

Relathionship between salinity $(\mathrm{x})$ and feed effiiency having coefficien value $\left(\mathrm{R}^{2}\right)$ was $80.9 \%$. it means any changing $80.9 \%$ of feed efficiency was affected by salinity. Based on formula $Y=37.04+21.75 \mathrm{x}+-4.73 \mathrm{x}^{2}$, was found an optimum salinity of $2.29 \mathrm{ppt}$ for feed efficiency.

The highest suvival rate was got from treatment of 0 ppt with $67.78 \%$, rearing media of $0 \mathrm{ppt}$ close to body fuid of climbing fish. So that the fish use energy minimal for osmoregulation proccess. According to Stickney [20], if environment osmotic pressure close to fish osmotic pressure, energi produced by metabolism would not be used for adapted to environment osmotic pressure. So that energy was more used for growth and survival. As well Chotipuntu dan Avakul [4] in their experiment showed climbing fish with size of $3-4 \mathrm{~cm}$ will ablle to adapt more high salinity compare to egg and larvae.

Relathionship between salinity $(x)$ and survival rate having coefficien value $\left(\mathrm{R}^{2}\right)$ was $72.0 \%$. it means any changing $72.0 \%$ of survival was affected by salinity. Based on formula $\mathrm{y}=73.04+0.54 \mathrm{x}+-0.30 \mathrm{x} 2$, was found an optimum salinity of $1.8 \mathrm{ppt}$ for survival rate.

Water quality measurement during experiment showed feasible for climbing fish. According to Rahman [18] water temperature of $26,06^{\circ}-31,97^{\circ} \mathrm{C}$ was suitable for fish culture. While ph on rearing media was $5.8-7.2$. According to Boyd (1982) in Rasmawan [19] $\mathrm{pH}$ would die fish if the $\mathrm{pH}$ less than 4 and more than 11. $\mathrm{pH} 5-10$ was the can survive, while the $\mathrm{pH}$ ini this experimen was till normal condition. Salinity in this experiment was control as the treatment. Salinity was fluktuated no more than 0.5 ppt. Disolved oxygen on rearing media was $5.41-9.41 \mathrm{mg} / \mathrm{l}$. According Peterson et al.(1999) disolved oxygen more than $4 \mathrm{mg} / \mathrm{l}$ was good for fish culture. Amonia contain ini this experiment was $0.60-1.7 \mathrm{mg} / \mathrm{l}$. This condition still feasible to fish for survive however if the amonia contain more than $2.4 \mathrm{mg} / \mathrm{l}$ will affect fish for death [3].

\section{Conclusion}

The optimum salinity for survival, specific growth rate, total weight gain and feed efficiency were $1.8 \mathrm{ppt}, 2.5 \mathrm{ppt}, 2,8 \mathrm{ppt}$ and 2,29 ppt.

\section{References}

1. H. Akbar. Bogor. Agr. Univ. 35 (2008)

2. J. Akbar, M. Adriani, S. Aisiah. J. Bionatura, 13, 9 (2011) 
3. I.M. Chotiba. Padjadjaran Univ. 40 (2014)

4. P. Chotipuntu, P. Avakul. Walailak J. 7, 7 (2010)

5. G. De Boeck, H. Smet, R. Blust. Physiol. Biochem. Zool. 73, 9 (2000)

6. S. Djarijah. Natural fish food. 87 (1995)

7. Y. Ernawati, M.M. Kamal, N.A.Y. Pellokila. J. Ikh. Ind. 9, 25 (2009)

8. Y.Fujaya. Fish physiology. 179 (2004)

9. C. Garcia, F. Pozet, C. Michel. Dis. Aquat. Organ. 42, 7 (2000)

10. Isriansyah, K. Sukarti. Mulawarman University, 3, (2007)

11. T. Kaneko, J. Hiroi. Fish Larval Physiology. 20, (2008)

12. E. B. Kuncoro. The popular encyclopedia of freshwater fish. 2, (2009)

13. H. Kurata. Mexican Journal of Agricultural Science. 20, 21 (1959)

14. Mudjiman. Fish food. 190 (1998)

15. F. Nahar. Dhaka university press. 72 (2014)

16. S. Najiyati, L. Muslihat. Know the Type of Peat Land. 4, (2015)

17. D. Rahmadani. Bogor. Agr. Univ. 80 (2007)

18. M.S. Rahman, M.Y. Chowdhyry, A.K.M.A. Fiaque, M.S. Haque. Bangl. J. Fish. Res. 5, 10 (1982)

19. Rasmawan. Bogor. Agr. Univ. 67 (2009)

20. R. R. Stickney. Principle of Warmwater Aquaculture. 375 (1979)

21. W. Ye, D. Cheng, L. Ma. J. Envirn. Bio. 1, 7 (1990)

22. R. Woo, M. Kelly. J. Fish. Phys. 78, 76 (1995) 